\title{
FELTÁRÓ KUTATÁS A HAGYOMÁNYOS ÉS TÁJJELLEGỨ ÉLELMISZEREK JELENTÓSÉGÉNEK MEGÁLLAPÍTÁSÁRA AZ ÉSZAK-ALFÖLDI RÉGIÓBAN
}

\author{
$\longrightarrow$

\section{PRELIMINARY RESEARCH IN CONNECTION WITH THE SIGNIFICANCE OF THE TRADITIONAL AND REGIONAL FOODS IN THE NORTH GREAT PLAIN REGION}

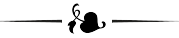 \\ ${ }^{1}$ HALASI, Nóra \\ ${ }^{2} N A ́ B R A ́ D I$, András \\ ?a. \\ ${ }^{1}$ Debreceni Egyetem, Gazdaságtudományi Kar, Ihrig Károly Gazdálkodás- és Szervezéstudományok Doktori Iskola \\ (University of Debrecen, Ihrig Károly Doctoral School of Management and Business Administration) \\ email: halasinora@freemail.hu \\ ${ }^{2}$ Debreceni Egyetem, Gazdaságtudományi Kar, Gazdálkodástudományi Intézet, Vállalatgazdaságtani nem önálló Tanszék \\ (University of Debrecen, Faculty of Economics and Business, Institute of Applied Economics, Department of Business Management)
}

\begin{abstract}
al The traditional and regional foods represent distinctive and unique values for customers in the world food market by their inimitable tastes and appearances. In today's fast-moving world in which globalization's different - both positive and negative - effects determine the daily activities of consumers and influence their needs, their choices and their decisions during the regular food and raw material purchases; it is relevant to strive for the presence and regular consumption of traditional products also to become known to a wide circle of society. The key objectives of our research are the main effects of traditional and regional foods in the Northern Great Plain, particularly with regard to the marketing and economic aspects approach. Our study is an experimental study of a later larger number of elements and representative survey, and it is based primarily on online questionnaires. During the research we received 151 available questionnaires. The interviewed inhabitants of the region have declared a positive opinion in the context of traditional and regional foods, most of them purchased and consumed these products regurarly.
\end{abstract}

KuLCSSZAVAK: fogyasztói magatartás, hagyományos és tájjellegű termék és élelmiszer, fogyasztói preferenciák, pozicionálás

JEL-KóD (JEL CODE): M31

\section{BeVEZETÉS - INTRODUCTION}

A hagyományos és tájjellegü termékek, valamint élelmiszerek tradicionális előállításuk, jellegzetes, a fogyasztók számára utánozhatatlan íz-világuk és megjelenésük révén különleges értékeket képviselnek a világ élelmiszerpiacán; ugyanakkor minden ország gazdaságában, kultúrájában és mindennapi életében megkülönböztetett helyet foglalnak el. Napjaink felgyorsult világában, amely során a globalizáció
KEYWORDS: consumer behavior, traditional and local product and food, consumer preferences, positioning különböző - pozitív és negatív - hatásai meghatározzák a fogyasztók mindennapi tevékenységeit, befolyásolják szükségleteiket, döntéseiket és választásaikat a rendszeres élelmiszer- és alapanyag-vásárlásaik során; indokolt törekedni a tradicionális termékek jelenlétére, rendszeres fogyasztására, és a társadalom széles rétegében történő ismertté válására. Emellett lokális és speciális jellegzetességeik miatt a hagyományos és tájjellegű élelmiszerek kiemelkedő szerepet játszanak a vidékfejlesztésben, 
a vidék népességmegtartó képességének megőrzésében és növelésében, ugyanakkor egyes mezőgazdasági kultúrák esetében maga a tájkép megőrzésében és javításában (NÂBRÁDI, 2010).

Egy adott térségre vonatkozóan nagyon fontos szerepet kap a versenyképesség és a fenntarthatóság kérdésköre, mely tényezők a helyi lakosok életminőségét és gazdasági helyzetét alapvetően meghatározzák. A lehetőséget és a fejlődés opcióját leginkább a vidékfejlesztés intenzív megvalósulása hordozza magában. A hagyományos és tájjellegú élelmiszer-termékek egyértelműen a vidéki területek fejlődésének lehetőségét jelentik, előállításuk rendkívül fontos a helyi - és összességében a magyar gazdaság, illetve társadalom szempontjából is. Ezen élelmiszer-termékek előállításának növelése, illetve az értékesítési lehetőségek kiterjesztése és emelése hozzájárulhat a régió egyes térségeinek népességmegtartásához, valamint többek között a vidéki területek tárgyi és szellemi örökségének védelméhez, megőrzéséhez. A városi területek is kiemelt jelentőséggel bírnak a hagyományos- és tájjellegü ételek szempontjából: a helyi rendezvények (például tematikus fesztiválok) és a vendéglátás szereplői tudatos, átgondolt értékesítési- és marketing stratégia révén szintén segíthetnek az élelmiszer-termékek népszerűvé tételében.

Magyarország - egyedülálló nemzeti specialitásai, gazdag és ízletes, mégis egyszerű és friss alapanyagokból készült hagyományos ételeiról egyaránt -világszerte ismert. Kutatásunk lényeges célja a hagyományos és tájjellegü élelmiszerek, illetve termékek gazdasági- és marketing pozíciójának jellemzése és elemzése a helyi fogyasztók körében, az Észak-alföldi régió területén. Elsősorban a helyi sajátosságokat vizsgáljuk, a régióbeli lakosok véleményét mérjük fel a hagyományos élelmiszer-vásárlással összefüggésben. A vásárlással kapcsolatos döntéseiben egyre több fogyasztó előnyben részesíti a mennyiséggel szemben a minőséget, és ezen feltételezések alapján vizsgáljuk az adott területek egyes mezőgazdasági és élelmiszeripari termékeit.

Kutatásunk során, a feltárt eredmények alapján - az adott földrajzi helyszínekre jellemző fogyasztói magatartások, attitűdök, preferenciák tükrében és a helyi termelők gaz- dasági- és marketingkörnyezetére vonatkozó információk birtokában - összegzésképpen megoldásokat kívánunk megfogalmazni, valamint javaslatokat tenni a jövőre vonatkozó hatékonyabb és eredményesebb fejlődés érdekében. Kutató munkánk feltáró szakaszában szakirodalmi források felhasználásával definiáljuk, illetve elhelyezzük a hagyományos és tájjellegü élelmiszereket az élelmiszerkategóriák rendszerében. A hagyományos és tájjellegü kifejezés számos sajátossággal bír. Nyilvánvalóan a helyi és hagyományos termékek leginkább a lokális vállalkozások és a turizmus szempontjából jelentősek, így nem alkalmasak a régió mélyebb strukturális problémáinak megoldására; ugyanakkor „támogató” szerepük révén segíthetnek a gazdaság fejlesztésében és a különböző társadalmi rétegek sajátos igényeinek kielégítésében.

\subsection{A hagyományos és tájjellegü élelmiszerek jelenléte az élelmiszerek piacán - Presence of Traditional and Regional Products in the Food Market}

Napjainkban a multinacionális vállalatok exponenciálisan növekvő piacfejlesztő tevékenysége és diverzifikációja révén a különböző fogyasztásra alkalmas élelmiszerek jellegzetes tulajdonságai, ízei, megjelenési formái és egyéb sajátos megkülönböztető jegyei egyre inkább egységessé és hasonlóvá válnak a világ minden táján. A globalizáció során ez a folyamat akadályozhatja a hagyományos és tájjellegü élelmiszerek értékesítését, amely különböző negatív gazdasági tendenciákat eredményezhet, többek között munkahelyet, megélhetést vesz el a helyi lakosságtól, csökkenti a termék-szortimentumot, a befizetett adó mértékét, a helyi gazdasági növekedést, kényszeríti a migrációt, növeli a munkanélküliséget, a nemzeti-, regionális- vagy helyi örökségek száma redukálódik (NÁBRÁDI, 2010). A kiváló minőségü és hagyományos termékekkel a magyar mezőgazdaság és élelmiszeripar képes lehet kihasználni az EU tagságból adódó előnyöket, valamint csökkenteni az esetleges hátrányokat (LAKNER és GULYÁS, 2004).

Az élelmiszer-fogyasztás speciális fogyasztási területnek tekinthető, amely az egyén és a 
gazdaság számára is jelentős, ugyanakkor az élelmiszer-fogyasztást általános, mindennapi fiziológiai szükségletek motiválják, és az élelmiszer nem dematerializálható vagy helyettesíthető más termékekkel. Lényeges, hogy az élelmiszer-fogyasztás tükrözi az életstílust és az értékeket is (LEHOTA, 2004.). Eltérés tapasztalható azonban a fejlődő és a fejlett országok élelmiszer-fogyasztása között. A fejlődő országokban az elégtelen kalória bevitel és az alultápláltság jellemző. A fejlődő országok ugyanakkor a túlzott kalória bevitel és mozgásszegény életmód következtében az elhízás és más betegségek negatív egészségügyi hatásaival, illetve környezeti következményeivel szembesülnek. A fejlődő országokban az egy főre jutó jövedelem növekedésével emelkedik az élelmiszer-fogyasztás, illetve a hús- és fehérjefogyasztás iránti igény. Ezzel szemben a fejlett országokban a fehérjefogyasztás stabilitása mellett a szénhidrát- és zsiradékfogyasztás növekedése jellemző, továbbá az egy fóre jutó élelmiszer- és kalóriafogyasztás túlzottan magas szintje (GERBENS-LEENES, NONHEBEL és KROL, 2010).

Napjainkban a fogyasztók egészségtudatosabb csoportjainál egyre jellemzőbbé válik, hogy elfordulnak a tömegtermékektől és tudatosan keresik a magasabb hozzáadott értékkel rendelkező, különleges minőségű és speciális táplálkozási igényeket kielégítő termékeket. A piac visszaigazolása alapján a táplálkozási elöny önmagában nem elég, hanem annak társulnia szükséges a természetes eredettel, a kiváló ízzel, színnel, állománnyal, gyüjtőnéven a nagy élvezeti értékkel, a jó megjelenéssel, a kényelemmel és az elfogadható árral (ROWAN, 2001). Emellett amennyiben a fogyasztók esetében fennáll, hogy erőteljesen és pozitívan viszonyulnak egy adott területhez, akkor ezek az attitűdök hatnak rájuk, amikor a származási területre utaló jelet észlelnek. Mindezek erősítik a fogyasztók bizalmát, továbbá befolyásolják az adott tájjellegű termék értékelését (LANS, ITTERSUM, DE CICCO és LOSEBY, 2001). A fogyasztók túl nagyra tartják azokat a termékeket/szolgáltatásokat, amelyek saját országukból származnak azokkal szemben, amelyeket más országokból importálnak. Mindezt annak ellenére teszik, hogy természetesen semmilyen tényekkel igazolható okuk nincs erre
(MALOTA, 2003). ELLIOTT and CAMERON (1992) szerint a fogyasztók esetében a hazai termék iránt általános a preferencia, ha a minőség és az ár közel egyenlő vagy jobb, mint a külföldi terméké, ugyanakkor, ha rosszabb minőségü a hazai termék, a külföldi terméket választják. Összességében a hazai élelmiszergazdaság fejlődésének kulcskérdése a hazai piaci pozíciók megerősítése, és az új fogyasztási trendekhez történő alkalmazkodás. A táplálkozás változatosságának, helyi sajátosságainak megőrzése, illetve a megváltozott életmódhoz illesztett újrafogalmazása olyan örömforrás és kulturális érték, amely belátható időn belül vállalkozói szinten és régiók vonatkozásában is a versenyképességet növelő, illetve befolyásoló tényező lehet (SZABÓ, 2009).

Funkcionális élelmiszernek tekinthető minden olyan táplálék, valamint táplálék-összetevő, amely valamilyen kedvező élettani hatással rendelkezik a hagyományos tápértéke mellett (EDDY, 1986). BÍRÓ (2004) meghatározása alapján a funkcionális élelmiszerek olyan módosított élelmiszerek, amelyeknek egészségügyi hasznuk van, összehasonlítva a nem módosított termékekkel. SZAKÁLY (2009) szerint azok az új élelmiszerek, amelyek egészségvédő hatásuk révén megelőzik, illetve lassítják az emberiséget sújtó civilizációs betegségek terjedését, az idősödő társadalmaknak pedig hosszabb egészségben eltöltött élettartamot biztosítanak, funkcionális élelmiszereknek tekinthetőek. A hagyományos és tájjellegú élelmiszerek SZAKÁLY et al. (2014) szerint a funkcionális jellegü élelmiszerek, természetes élelmiszerfejlesztési irány kategóriájába sorolhatóak, melyet az alábbi 1. ábra szemléltet.

A hagyományos és tájjellegű termékek különleges minőséggel rendelkeznek, amely a termék előállításához kötődő hagyományokból, a táj jellegzetességeiből és a termék történetéből adódik. (PALLÓNÉ KISÉRDI, 2003). Hagyományos és tájjellegű terméknek/élelmiszernek nevezzük azokat a mezőgazdasági termékeket és élelmiszereket, amelyeket tradicionális módon állítanak elő, történelmi múlttal rendelkeznek, kötődnek egy adott térséghez, ahol napjainkban is jelen vannak az élelmiszerpiacon. A definíció szinonimájaként alkalmazhatóak a hagyományos, a tradicionális, a nemzeti és a hungarikum termék/élelmiszer kifejezé- 
sek, a termékek közös gyűjteménye a Hagyományok-Ízek-Régiók gyưjtemény. Ugyanakkor eltérnek a fogalomtól a regionális és helyi termékek, mert azok csak egy szúkebb területhez való kötődést jelentenek, de előállításuk nem függ össze a tradíciókkal (SZAKÁLY, PALLÓNÉ KISÉRDI és NÁBRÁDI, 2010). A regionális termék az adott régiónak köszönhető minőséggel és ismertséggel rendelkezik, amelynek piacra jutásában a régiónak, mint megnevezésnek is kulcsszerepe van (ITTERSUM, 2002). Mindezeken kívül konvencionális, klasszikus, vagy tömegterméknek/élelmiszernek definiálhatóak azok a nagy tételben, ipari körülmények között előállított élelmiszeripari termékek, amelyek megfelelnek az általános előírásoknak, nincs speciális alapanyag- és technológiaigényük, ugyanakkor a kereskedelmi forgalomban megtalálhatóak. A konvencionális termékeket a kereskedelmi forgalomban eltérő márkázással differenciálják. Az öko(ológiai), bio(lógiai) vagy organikus termék/élelmiszer pedig olyan gazdálkodásból származhat, ahol nem alkalmaznak ember által készített mütrágyákat, növényvédő és rovarirtó szereket, növekedésszabályozókat és takarmány-kiegészítőket. Mindezek helyett a rendszer a vetésforgóra, az állati és növényi eredetű trágyákra, a kézi jellegű gyomirtásra és a különböző kártevők elleni biológiai védekezésre épül. A termék-előállítás szigorú előírások alapján, rendszeres termékés minőségtanúsítás mellett zajlik (SZAKÁLY, PALLÓNÉ KISÉRDI és NÁBRÁDI, 2010). Külön csoportot alkotnak a kézmúves élelmiszerek, amelyek egyedi jelleggel bírnak, továbbá előállításuk során a különös gondosság, a „mívesség”, a kézzel végzett és a szaktudás által irányított munkafolyamatok dominálnak. A termékeket elsősorban kézi technológiával állítják elő, és bár egyes munkafolyamatok gépesíthetők, az előállításnak a közvetlen emberi irányításon és kézi munkavégzésen, az emberi erőfeszítésen és tapasztalaton kell alapulnia (ÉLELMISZERLÁNC, 2016).
Az Észak-alföldi régió hagyományos élelmiszerei egyedi illatuk és íz-világuk révén lehetôséget adnak a helyi gasztronómia népszerüvé tételére a belföldi- és külföldi turisták számára egyaránt, ugyanakkor értékesítésük hozzájárulhat a gazdaság fejlődéséhez is.

A régió jellegzetes termékcsoportjai, termékei a következők (SZAKÁLY, PALLÓNÉ KISÉRDI és NÁBRÁDI, 2010; CSERHALMI et al., 2001):

- Hús: Hortobágyi (racka) juh, Magyar szürke szarvasmarha,

- Zöldség-gyümölcs: Nagydobosi sütőtök, Hajdúsági torma, Besztercei szilva, Milotai dió,

- Ital: Szatmári szilvapálinka, Diópálinka,

- Cukrász és pékáru: Debreceni vert mézes, Debreceni vásári füzéres perec, Kürtőskalács,

- Száraztészták: csigatészta, kötött tészta.

A régió leginkább mezőgazdasági jellege miatt a „Hagyományok-Ízek-Régiók” programban sok termékkel szerepel. A gyüjteménybe bekerült háromszáz termék közül közel minden ötödik termék (19,3\%) a régióból származik. Mindezek között meghatározott pozíciót foglalnak el a termesztett, gyưjtögetett és feldolgozott gyümölcsök (alma, szilva, körte, meggy, köszméte, dió); a termesztett, gyưjtögetett és feldolgozott zöldségek (hajdúsági káposzta, torma; kisvárdai burgonya, nagydobosi sütőtök, mezei szekfügomba, sziki csiperke); valamint a sütőipari termékek és száraztészták. Lényeges megállapítás, hogy az Európai Unió tormatermésének 45-50\%-át a régióból származó Hajdúsági torma jelenti. Jelentősek a hagyományos állatfajok is, például a Magyar szürke szarvasmarha és a magyar kecske. Ugyanakkor a feldolgozott tejtermékek és húskészítmények aránya, illetve ismertsége kisebb, mint a növényi eredetű élelmiszereké (MAKAY, 2006). 


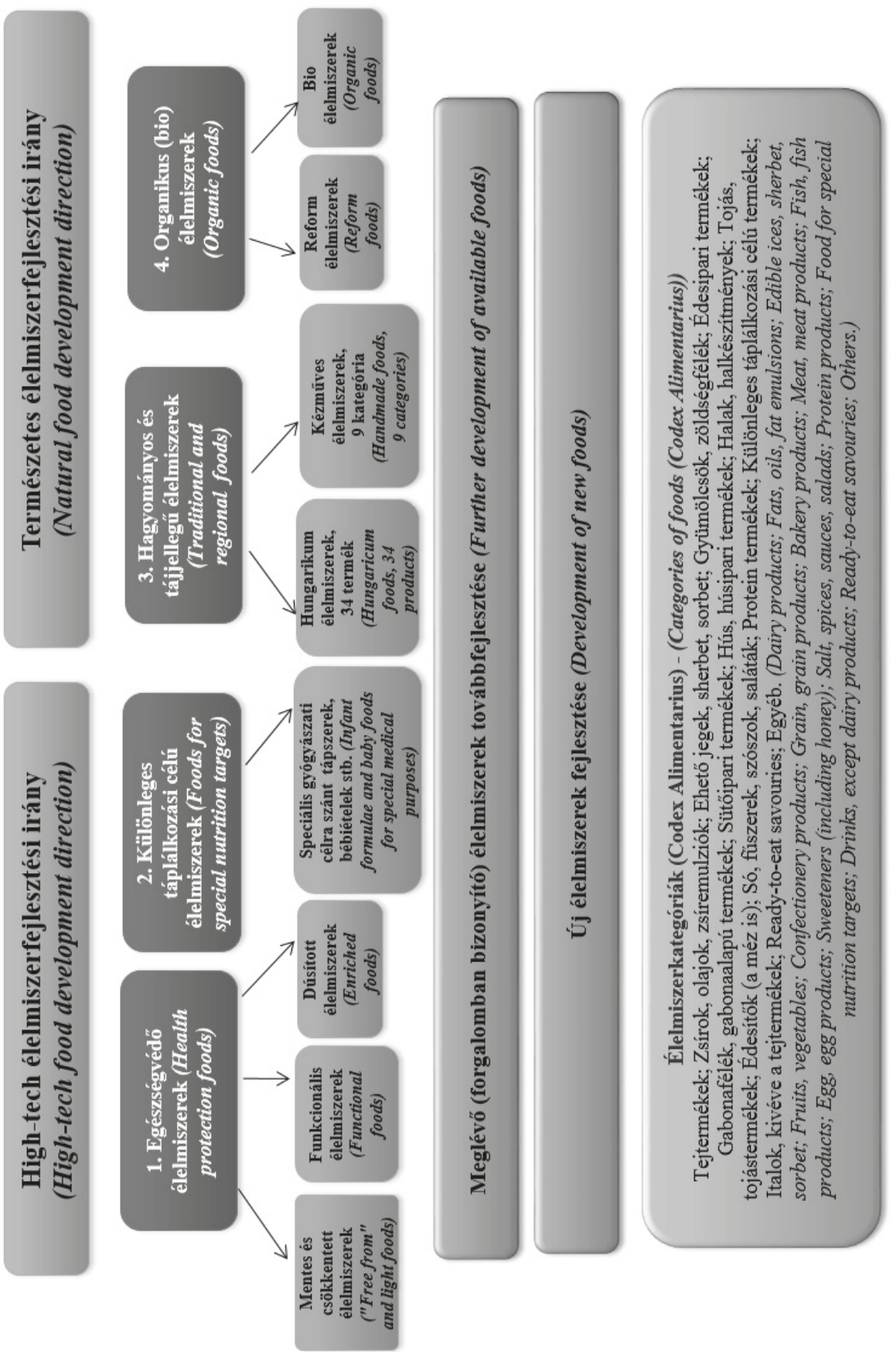

1. ÁBRA

A perspektivikus (funkcionális jellegü) élelmiszerek

FIG. 1 (Perspective (Functional) Foods) 


\section{ANYAg ÉS MóDSZER - MATERIALS} AND METHODS

A témakörrel kapcsolatos ismeretanyagot primer-, illetve szekunder kutatási módszerek révén egyaránt feldolgoztuk és elemeztük. A szekunder kutatás által meghatároztuk az élelmiszerfogyasztás jellemzőit, valamint a legfontosabb ezzel kapcsolatos trendeket és fogalmakat a fogyasztói magatartás vonatkozásában. Különböző, az adott országra és régióra jellemző gazdasági adatok, felmérések és elemzések jelentik a kutatásunk egyik lényeges alapját. Nagyon fontosnak tartjuk a hagyományos és tájjellegü élelmiszerek Magyarországra és az Észak-alföldi régióra gyakorolt imázs-építő hatását, melyet nemzetközi és hazai szakirodalmi áttekintések révén is vizsgáltunk.

Primer kutatásunk során a kvantitatív (mennyiségi) módszerek közül a megkérdezés módszerét alkalmazzuk, kérdőíves vizsgálat formájában. A kérdések leginkább a fogyasztók hagyományos- és tájjellegü élelmiszerekkel kapcsolatos preferenciáit, ismereteit, vásárlási szokásait, észleléseit és kockázatkezelését elemzik. A kérdőíves felmérés során kiemelt célunk, hogy értékelhetővé váljon a hagyományos és tájjellegü élelmiszerekért való többletfizetési hajlandóság, illetve következtetéseket lehessen levonni, hogy melyek a legfontosabb gazdasági feltételek az élelem-előállítás során.

A jelen felmérés elővizsgálat egy sokkal nagyobb elemszámú és reprezentatív felméréshez, melyben tesztelésre került, hogy a további vizsgálat során melyek lehetnek a kiugró értékek, illetve milyen sajátosságok jellemezhetik az Észak-alföldi régió hagyományos és tájjellegű élelmiszerfogyasztását. A kutatás feltáró szakaszában hét zárt kérdést fogalmaztunk meg a hagyományos és tájjellegű élelmiszerekkel kapcsolatban:

1. Személyes jövedelméhez képest milyennek tartja a magyarországi hagyományos élelmiszer termékek árát?

2. Mennyire fontos Önnek, hogy az adott élelmiszer termék helyi alapanyagok felhasználásával készüljön?
3. Hajlandó lenne-e többet fizetni, egy hagyományos helyi alapanyagokból készült élelmiszer termékért (Pl. parenyica sajt)?

4. Ha igen, mennyivel lenne hajlandó többet fizetni az adott termékért?

5. Vonzónak és érdekesnek tartja-e a hagyományos alapanyagokkal összefüggésben tartott rendezvényeket (pl. sajtfesztivál, mangalicafesztivál, pálinkafesztivál, termékvásárok)?

6. Hajlandó lenne-e többet fizetni egy ilyen jellegü rendezvényen, egy hagyományos helyi alapanyagokból készült termékért (pl. debreceni páros kolbász, penyigei szilvalekvár)?

7. Amennyiben igen, mennyivel lenne hajlandó többet fizetni az adott termékért?

A háttérváltozók esetében demográfiai kérdéseket fogalmaztunk meg (életkor, nem, iskolai végzettség, gazdasági aktivitás, településtípus) valamint a válaszadó jövedelmi helyzetére kérdeztünk rá.

A kvantitatív kérdőíves felmérésre 2015. május és 2016. november hónap között került sor. Az adatgyüjtés során a megkérdezést következetesen végeztük, csak az adott régió lakosainak válaszait vettük figyelembe. Hajdú-Bihar, Szabolcs-Szatmár-Bereg és Jász-Nagykun-Szolnok megye lakosaira vonatkozóan a megkérdezést kizárólag online formában, interneten keresztül végeztük. A kérdőív a Google Docs ürlapkészítő alkalmazással készült, a felmérésben a részvétel önkéntes volt. Az online kérdőív egy közösségi oldal felületén volt elérhető, mely során 151 fö töltötte ki a kérdőívet, akik közül valamennyien értékelhető választ adtak. Az Észak-alföldi régióban összesen 151 fő ( $\mathrm{n}=151)$ a megkérdezett minta nagysága. Tisztában vagyunk azzal, hogy a válaszadók száma relatíve kevés és a kapott eredmények alapján levonható következtetések nem tekinthetőek reprezentatívnak. A kutatás feltáró szakaszában nem is ez volt a fő célkitüzésünk, hanem, hogy milyen irányban végezzünk nagyobb elemszámú, statisztikailag is igazolható összefüggéseket a hagyományos és tájjellegű élelmiszerek vonatkozásában. 


\section{EREDMÉNYEK - RESUltS}

\subsection{A minta szocio-demográfiai jellemzői - Social-demographic Attributes of the Sample}

A megkérdezett személyek egyes háttérváltozók szerinti megoszlását az alábbi 1. táblázat szemlélteti.

A minta demográfiai jellemzőinél nemek, korcsoportok, iskolai végzettség és lakóhely szerint kategóriákat állítottunk fel, illetve a to- vábbi kutatások lehetőségeihez az egy főre jutó jövedelem összegeiről is információkat kértünk. A válaszadók közül a nők aránya 60,3\%, legnagyobb arányban a 18-22 éves korosztály válaszolt kérdéseinkre, melynek tagjai meghatározó mértékben közép- és felsőfokú végzettséggel rendelkeznek. A válaszadók több mint 60\%-a megyeszékhelyen lakik, és viszonylagosan alacsony a 10 ooo lakos alatti településről érkezett válaszok száma. A mintában szereplő válaszadók átlagos jövedelme 111,75 ezer Ft volt.

1. TÁBLÁZAT

TABLE 1

A minta bemutatása (Introduction of the Sample) $(\mathrm{N}=151)$

\begin{tabular}{|c|c|c|}
\hline Demográfiai csoportok (Demographic Groups) & No & $\%$ \\
\hline \multicolumn{3}{|l|}{ Nemek szerint (Gender) } \\
\hline Férfi (Men) & 60 & 39,7 \\
\hline Nő (Women) & 91 & 60,3 \\
\hline \multicolumn{3}{|l|}{ Korcsoportok (Age groups) } \\
\hline 18-29 éves (18-29 years) & 54 & 35,8 \\
\hline 30-39 éves (30-39 years) & 45 & 29,8 \\
\hline 40-49 év (40-49 years) & 28 & 18,5 \\
\hline $50-59$ éves ( $50-59$ years) & 13 & 8,6 \\
\hline 60 éves kor felett (older than 60 years) & 11 & 7,3 \\
\hline \multicolumn{3}{|l|}{ Iskolai végzettség szerint (Qualification) } \\
\hline 8 általános (Elementary School) & 0 & 0,0 \\
\hline Szakmunkás képző (Vocational School) & 11 & 7,3 \\
\hline Érettségi (High School Degree) & 66 & 43,7 \\
\hline Felsőfokú végzettség (University Degree) & 74 & 49,0 \\
\hline \multicolumn{3}{|l|}{ Lakóhely településtípusa (Habitation) } \\
\hline Megyei jogú város, megyeszékhely (City of County) & 92 & 60,9 \\
\hline 10 ooo lakos feletti város (1o ooo+ Settlement) & 18 & 11,9 \\
\hline 2 ooo-10 ooo lakos közötti település (Settlement between 2 ooo and 10 ooo) & 37 & 24,5 \\
\hline 2 ooo lakos alatti település (Settlement under 2 OoO) & 4 & 2,6 \\
\hline \multicolumn{3}{|c|}{$\begin{array}{c}\text { Szubjektív jövedelmi helyzet, a családban } 1 \text { före jutó jövedelem összege (Perceived income level, the amount of the family } \\
\text { income per capita) }\end{array}$} \\
\hline Kevesebb, mint 50 ooo Ft (Less than 50 ooo Ft) & 8 & 5,3 \\
\hline 50 ooo - 75 ooo Ft (Between 50 ooo and 75 ooo Ft) & 25 & 16,6 \\
\hline 75 ooo - 100 ooo Ft (Between 75 ooo and 100 ooo Ft) & 37 & 24,5 \\
\hline $100000-150000 \mathrm{Ft}$ (Between 100 ooo and $150 \mathrm{ooo} F t$ ) & 37 & 24,5 \\
\hline 150 ooo - 200 ooo Ft (Between 150 ooo and 200 ooo Ft) & 8 & 5,3 \\
\hline 200 ooo Ft felett (More than $200 \mathrm{ooo} F t$ ) & 10 & 6,6 \\
\hline $\mathrm{NT} / \mathrm{NV}$ (N.A.) & 26 & 17,2 \\
\hline
\end{tabular}

Forrás (Source): Saját adatfeldolgozás, 2016 (Own data, 2016) 


\subsection{Hipotézisvizsgálatok - Hypothesis Testing}

A feltáró kutatás során a kérdőívben hét kérdés szerepelt a hagyományos és tájjellegú élelmiszerekkel összefüggésben, a célunk annak megállapítása volt, hogy létezik-e összefüggés az egyes háttérváltozók és az adott kérdés között. Ennek érdekében a jelen felmérés során négy hipotézist fogalmaztunk meg, melyekre vonatkozóan összefüggés vizsgálatokat végeztünk.

\subsubsection{Az első hipotézis - \\ H1 (The First Hypothesis - H1)}

$\mathrm{Az}$ élelmiszerek vásárlásánál meghatározó tényező a jövedelem, hiszen a fogyasztók tudatosságra való törekvését és választásait nagymértékben determinálja az egy főre jutó jövedelem nagysága. A kérdőívben a következő kérdésre adott válaszok alapján vizsgáltuk a hipotézis igazolását: személyes jövedelméhez képest milyennek tartja a magyarországi hagyományos élelmiszer termékek árát? Ez által arra kerestük a választ, hogy az adott válaszadó miként értékeli a hagyományos és tájjellegư élelmiszereket, az egyes jövedelemkategóriák függvényében. A hagyományos és tájjellegű élelmiszerek árának megítélését a vásárlók családjainak egy főre jutó jövedelemhelyzete alapján a 2. táblázat ismerteti.

A 118 válaszadó véleményét a Pearson-féle khí-négyzet $\left(\chi^{2}\right)$ próba számítási eljárásába építettük. A H1 hipotézis akkor lenne igazolható, ha a $\chi^{2}$ értéke a kritikus értéknél magasabb lenne. Esetünkben a kritikus érték (25), ugyanakkor a khí négyzet értéke 8,1088. Ez azt jelenti, hogy a H1 elvetendő, vagyis nincs szignifikáns összefüggés a hagyományos és tájjellegü élelmiszerek vásárlása, valamint az egy főre jutó jövedelem nagysága között $\left(\chi^{2}=8,1088\right.$. $\mathrm{p}<$ 0.005).

A megkérdezett fogyasztók több mint kétharmada $(66,9 \%)$ drágának ítélte meg a hagyományos és tájjellegű termékek árát, melyet a vásárlók közel egynegyede (24,6\%) reálisnak és megfizethetőnek tartott, és mindössze 8,5\%-uk jellemezte az élelmiszer árakat irreálisan drágának. Az összes válaszadó 21,2\%-ának családjában az 1 főre jutó jövedelem összege 75-100 ezer Ft, illetve szintén 21,2\% esetében 100-150 ezer Ft volt, mely vásárlók valamennyien drágának tartották a hagyományos és tájjellegư élelmiszereket.

2. TÁBLÁZAT

TABLE 2

A hagyományos és tájjellegú élelmiszerek árának megítélése a vásárlók családjainak egy főre jutó jövedelemhelyzete alapján, \%

(The Judgement of the Price of Regional Food Based on the Per Capita Income Situation of the Families of Customers, \%)

\begin{tabular}{|c|c|c|c|c|c|c|c|}
\hline \multirow{2}{*}{$\begin{array}{l}\begin{array}{l}\text { Szempontok } \\
\text { (Categories) }\end{array} \\
\text { Árak/Egy före jutó } \\
\text { jövedelem (ezer Ft) } \\
\text { (Prices/Income per capita, } \\
\text { thousand HUF) }\end{array}$} & \multicolumn{6}{|c|}{$\begin{array}{c}\text { Jövedelemkategóriák és a válaszadók százaléka } \\
\text { (Income categories and percentages of respondents) }\end{array}$} & \multirow[b]{2}{*}{ 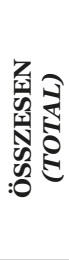 } \\
\hline & $\begin{array}{c}\mathrm{O}-50 \\
\text { ezer Ft } \\
(O-50 \\
\text { thousand } \\
\text { HUF) }\end{array}$ & $\begin{array}{c}50-75 \\
\text { ezer Ft } \\
(50-75 \\
\text { thousand } \\
\text { HUF) }\end{array}$ & $\begin{array}{c}75-100 \\
\text { ezer Ft } \\
(75-100 \\
\text { thousand } \\
\text { HUF) }\end{array}$ & $\begin{array}{c}100-150 \\
\text { ezer Ft } \\
(100-150 \\
\text { thousand } \\
\text { HUF) }\end{array}$ & $\begin{array}{c}150-200 \\
\text { ezer Ft } \\
(150 \\
-200 \\
\text { thousand } \\
\text { HUF) }\end{array}$ & $\begin{array}{c}200 \text { ezer } \\
\text { Ft felett } \\
\text { (Above } 200 \\
\text { thousand } \\
\text { HUF) }\end{array}$ & \\
\hline $\begin{array}{l}\text { Irreálisan drága (Extemely } \\
\text { expensive) }\end{array}$ & 0,0 & 0,8 & 2,5 & 2,5 & 1,7 & 0,8 & 8,5 \\
\hline Drága (Expensive) & 5,1 & 12,7 & 21,2 & 21,2 & 3,4 & 3,4 & 66,9 \\
\hline $\begin{array}{l}\text { Reális és megfizethető } \\
\text { (Reasonable) }\end{array}$ & 1,7 & 7,6 & 5,1 & 5,9 & 1,7 & 2,5 & 24,6 \\
\hline Olcsó (Cheap) & 0,0 & 0,0 & 0,0 & 0,0 & 0,0 & 0,0 & 0,0 \\
\hline ÖSSZESEN (TOTAL) & 6,8 & 21,2 & 28,8 & 29,7 & 6,8 & 6,8 & 100,0 \\
\hline
\end{tabular}

Forrás (Source): Saját felmérés, 2016 (Own survey, 2016) 
3.2.2. A második hipotézis - H2 (The Second Hypothesis - H2)

A hagyományos és tájjellegü élelmiszereket fogyasztók körében lényeges ismerni a vásárlás helyszínét. A második hipotézis igazolásának céljából a következő kérdésre adott válaszokat elemeztük: milyen jellegü üzletekben szokott a leggyakrabban élelmiszert vásárolni? A lehetséges válaszok a következők voltak: kisebb élelmiszerbolt, szupermarket, hipermarket, piac, diszkont, közvetlenül a termelőtől, egyéb, illetve nem vásárol ilyen jellegü termékeket. Az egyes vásárlók üzlettípus választását a megkérdezettek nemének összefüggésében vizsgáltuk, mely választások megoszlását a 2. ábra szemlélteti.

A válaszadók körében az élelmiszer vásárlás helye többnyire a szupermarket (43\%), ezt követően közel azonos arányban a hipermarket (22,5\%) és a kisebb élelmiszerboltok (22,7\%). A megkérdezettek egyaránt 5,3\%-a jelölte meg a piacot és a diszkontokat a vásárlás helyszínéül, $0,7 \%$-uk közvetlenül a termelőtől, illetve egyéb forrásokból (0,7\%) választ.

A H2 szerint előzetesen megállapítottuk, hogy nincs kimutatható kapcsolat a válaszadók neme és az üzlettípus választás között a hagyományos és tájjellegü élelmiszerek vásárlása során.

A 150 válaszadó véleményét a Pearson-féle khí-négyzet $\left(\chi^{2}\right)$ próba számítási eljárásába építve az alábbi eredményeket kaptuk: $\chi^{2}=4,948$. (kritikus érték: 11,1; elfogadási tartomány: (o - 11,1). A második hipotézis esetében is a H2 akkor lenne igazolható, ha a $\chi^{2}$ értéke a kritikus értéknél magasabb lenne. Esetünkben a kritikus érték (11,1), ugyanakkor a khí négyzet értéke 4,948, mely azt jelenti, hogy a H1 elvetendő. Összességében nem állapítható meg szignifikáns összefüggés a megkérdezettek neme és a vásárlás helyszínének kiválasztása között.

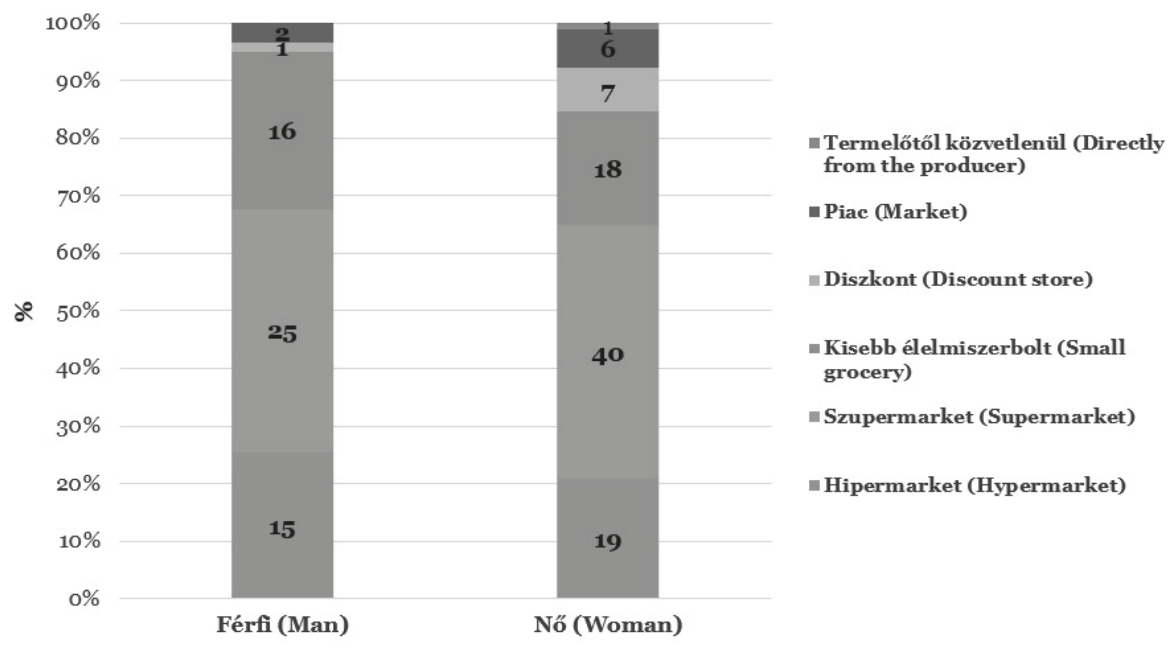

2. ÁBRA

Üzletválasztás nemek szerinti eloszlásban

FIG. 2 (Retailer Choices According to Genders)(N=150)

Forrás (Source): Saját szerkesztés, 2016 (Own construction, 2016) 


\subsubsection{A harmadik hipotézis - H3 (The Third Hypothesis - $\mathrm{H}_{3}$ )}

A harmadik hipotézis vizsgálatánál arra kerestük a választ, hogy van-e kimutatható kapcsolat, miszerint ha a fogyasztó előnyben részesíti vásárlásainál a magyar élelmiszer termékeket a külföldivel szemben, akkor a tematikus rendezvényeket (a hagyományos alapanyagokkal összefüggésben tartott rendezvényeket pl. sajtfesztivál, mangalicafesztivál, pálinkafesztivál, termékvásárok, stb.) is vonzónak találja-e? 147 értékelhető választ kaptunk, melynek alapadatai a 3. táblázatban kerültek szemléltetésre.

A hipotézis vizsgálatot elvégezve beigazolódott, hogy a két ismérv közötti kapcsolat független, amennyiben egy fogyasztó előnyben részesíti a magyar termékeket, az nem determinálja a tematikus rendezvények vonzó megítélését. $\left(X^{2}=6,41\right.$; a kritikus érték: 7,81; elfogadási tartomány: $0-7,81)$.

A megkérdezettek több mint négyötöde (83,7\%) tartja vonzónak a tematikus rendezvényeket. Az összes fogyasztó közel fele (46,3\%) gyakran, közel egynegyede (23,8\%) mindig, ugyanakkor 13,6\%-a ritkán részesíti előnyben vásárlásai során a magyar élelmiszereket a külföldivel szemben, ezek a válaszadók vonzónak tartották a hagyományos alapanyagokkal öszszefüggésben tartott rendezvényeket is.

A harmadik hipotézisvizsgálat adattáblája, \% (The Data-Plate of the Third Hypothesis, \%)

\begin{tabular}{lcc|c}
\hline \multirow{2}{*}{$\begin{array}{c}\text { Elönyben részesíti } \\
\text { a magyar terméket } \\
\begin{array}{c}\text { (Preference for } \\
\text { Hungarian products) }\end{array}\end{array}$} & $\begin{array}{c}\text { Vonzónak tartja a tematikus rendezvényeket } \\
\text { (Appealing on thematic events) }\end{array}$ & \multirow{2}{*}{ ÖSSZESEN (TOTAL) } \\
\cline { 2 - 3 } Soha (Never) & Igen (Yes) & Nem (No) & 0,7 \\
\hline Ritkán (Rarely) & 0,0 & 4,1 & 17,7 \\
\hline Gyakran (Often) & 13,6 & 7,5 & 53,7 \\
\hline Mindig (Always) & 46,3 & 4,1 & 27,9 \\
\hline ÖSSZESEN (TOTAL) & 23,8 & 16,3 & 100,0 \\
\hline
\end{tabular}

Forrás (Source): Saját felmérés, 2016 (Own survey, 2016)

\subsubsection{A negyedik hipotézis - H4 (The Fourth Hypothesis - $\mathrm{H}_{4}$ )}

A negyedik hipotézis vizsgálatnál arra kerestük a választ, hogy a fogyasztó az élelmiszerek vásárlása esetén milyen szempontokat vesz figyelembe a választásnál? Azt feltételeztük, hogy az élelmiszerek vásárlásánál nincs kimutatható kapcsolat a fogyasztó döntése és néhány marketingtényező (ismert márka, gyakran vásárolt és megszokott márka, akciók, reklámok, család és barátok ajánlása) között. Ismeretes előttünk, hogy a vizsgálat szakmailag alátámasztottan akkor lehetséges, ha az egyes tényezőket külön-külön vizsgáljuk, de itt elsősorban nem a marketing eszközökön, hanem a hagyományos és tájjellegú élelmiszerek választási szempontjain volt a hangsúly. A válaszadás eredményeit a 4. táblázatban láthatjuk.
Az elemzés eredménye szignifikancia vizsgálattal azt eredményezte, hogy az összefüggés statisztikailag igazolható ( $\chi 2=132,8806$; a kritikus érték: 26,3; elfogadási tartomány: o - 26,3), tehát szignifikáns összefüggés mutatható ki a vásárló döntése és a vizsgált marketingtényezők (ismert márka, gyakran vásárolt és megszokott márka, akciók, reklámok, család és barátok ajánlása) között.

A megkérdezettek közel háromnegyedének (71,3\%) a választásnál inkább fontos (38\%), illetve közepesen fontos (33,3\%) volt, hogy a termék márkája ismert. A fogyasztók közel fele (46,6\%) vásárlásai során inkább fontosnak tartotta a gyakran vásárolt és megszokott márkájú élelmiszereket, közel egynegyedük (23\%) nagyon fontosnak, illetve azonos arányban közepesen fontosnak ítélte meg ezt a tényezőt. A vásárlók több mint fele (50,3\%) inkább fon- 
tosnak jelölte meg az akciókat a döntésénél, több mint egyötödük (22,4\%) ezt a szempontot nagyon fontosnak, közel egyötödük $(18,4 \%)$ közepesen fontosnak tartotta. A reklámok hatása a vásárlás során közepesen fontos volt a válaszadók 38,7\%-ánál, egyötödüknek inkább fontos, szintén egyötödüknek inkább nem fon- tos szempont volt a marketingtényező. A család és barátok ajánlása a vásárlók több mint kétharmadát $(69,4 \%)$ szintén befolyásolta, 35,4\%ának inkább fontos és 34\%-ának közepesen fontos szempont volt ez a tényező élelmiszervásárlásuk során.

4. TÁBLÁZAT

Hagyományos élelmiszerek vásárlása esetén, fontosságát tekintve

TABLE 4 milyen szempontokat vesz figyelembe?, \%

(During the Importance of Purchasing Traditional Food What are the Preferences?, \%)

\begin{tabular}{|c|c|c|c|c|c|c|}
\hline \multirow[b]{2}{*}{$\begin{array}{l}\text { Szempontok } \\
\text { (Categories) }\end{array}$} & \multicolumn{5}{|c|}{ Fontosság (Importance) } & \multirow{2}{*}{ 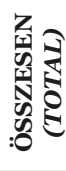 } \\
\hline & $\begin{array}{l}\text { Egyáltalán } \\
\text { nem fontos } \\
\text { (Non } \\
\text { important) }\end{array}$ & $\begin{array}{c}\text { Inkább } \\
\text { nem fontos } \\
\text { (Less } \\
\text { important) }\end{array}$ & $\begin{array}{c}\text { Közepesen } \\
\text { fontos } \\
\text { (Average } \\
\text { important) }\end{array}$ & $\begin{array}{c}\text { Inkább } \\
\text { fontos } \\
\text { (More } \\
\text { important) }\end{array}$ & $\begin{array}{c}\begin{array}{c}\text { Nagyon } \\
\text { fontos }\end{array} \\
\text { (Extemely } \\
\text { important) }\end{array}$ & \\
\hline $\begin{array}{l}\text { Ismert márka (Well- } \\
\text { known brand name) }\end{array}$ & 3,3 & 12,0 & 33,3 & 38,0 & 13,3 & 100,0 \\
\hline $\begin{array}{l}\text { Gyakran vásárolt, } \\
\text { megszokott márka } \\
\text { (Frequently } \\
\text { purchased, } \\
\text { customary brand) }\end{array}$ & 1,4 & 6,1 & 23,0 & 46,6 & 23,0 & 100,0 \\
\hline Akciók (Offers) & 0,7 & 8,2 & 18,4 & 50,3 & 22,4 & 100,0 \\
\hline $\begin{array}{l}\text { Reklámok } \\
\text { (Advertisement) }\end{array}$ & 18,7 & 20,0 & 38,7 & 20,0 & 2,7 & 100,0 \\
\hline $\begin{array}{l}\text { Család, barátok } \\
\text { ajánlása (Offered } \\
\text { by friends, family } \\
\text { members) }\end{array}$ & 5,4 & 10,9 & 34,0 & 35,4 & 14,3 & 100,0 \\
\hline ÖSSZESEN (TOTAL) & 5,9 & 11,5 & 29,5 & 38,0 & 15,1 & 100,0 \\
\hline
\end{tabular}

Forrás (Source): Saját felmérés, 2016 (Own survey, 2016)

\section{KÖVETKEZTETÉSEK ÉS}

\section{JAVASLATOK - CONCLUSIONS AND SugGESTIONS}

Összhangban MAGDA és MARSELEK (2010) kijelentésével, megállapításunk szerint a vidéki társadalom és a vidéki területek felértékelődéséről beszélhetünk, ugyanakkor maga a vidék súlyos válsághelyzetben van. Az eltérő dinamikájú területi fejlődés, növekvő különbségeket teremt az egyes vidéki területek között, mely révén sérül az esélyegyenlőség. A végső cél azonban mindenképpen a vidéken élők életminőségének javítása, valamennyi érintett gazdasági szereplő bevonásával, amelyhez nél- külözhetetlen a hagyományos és tájjellegű élelmiszerek jelenléte a piacon.

A régióban megkérdezett lakosok pozitív véleménnyel nyilatkoztak a hagyományos és tájjellegű élelmiszerekkel összefüggésben, felmérésem szerint többnyire rendszeresen vásárolják és fogyasztják ezeket a termékeket. A termékek piaci jelenléte esetében ugyanakkor a racionalitás szempontjából érdemes lenne hangsúlyozni a gazdaságosságot, esetlegesen a versenytársakhoz képest kedvezőbb árat, illetve a kiváló minőséget, mely tényezők fokozzák a vásárlók megelégedettségét, illetve a vásárlás hasznosságának érzését. Ez a megállapítás azzal is alátámasztható, hogy nincs szignifikáns összefüggés a családok jövedelmi helyzete és 
a hagyományos élelmiszerek vásárlása között. Emocionális szempontból is indokolható, hogy a származási hely ismeretét, a megbízható eredetet, a termék nyomon követhetőségét, továbbá a vásárló tájékoztatását lehetne a középpontba helyezni.

A hagyományos és tájjellegü élelmiszerek fogyasztása illeszkedik napjaink fogyasztói trendjeihez. A fogyasztók szívesen vásárolnak magyar terméket, elfogadják a hagyományos alapanyagokkal összefüggésben tartott rendezvényeket, bár ez utóbbi statisztikailag még nem igazolható. Emiatt is javasolható, hogy a jövőben a kínálati oldalnak törekednie kell a fogyasztók bizalmának elnyerésére, illetve megerősítésére, melynek kiváló eszköze a direkt és közvetlen értékesítési lehetőségek - termelői piac, vásárcsarnok - alkalmazása. Emellett a megkérdezettek közel fele válaszolta, hogy szupermarketben végzi vásárlásait, tehát a jó minőségű és egyedi hagyományos élelmiszereknek elérhetőnek kell lenniük a nagyobb bevásárlóközpontok polcain is.

\section{IRODALOMJEGYZÉK - REFERENCES}

Bíró Gy.: Új funkcionális élelmiszer alkotórészek - A rosszindulatú daganatok és az oxidatív degradáció. Édesipar. 2004. 50 (4) 137-146.

Cserhalmi Zs. - Csoma Zs. - Némethyné Uzoni H. - Sipos B. Z. - Szabó E. (szerk.): Hagyományok Ízek Régiók. Magyarország hagyományos és tájjellegü mezőgazdasági és élelmiszeripari termékeinek gyújteménye. I. kötet. Kesztler Marketing Kft., Budapest, 2001. 208-329.

Eddy, D. N.: Setting Priorities for Cancer Control Programs. Journal of the National Cancer Institute. 1986. 76 (2) 187-199.

Élelmiszerlánc: Magyar Élelmiszerkönyv. 2-109. számú irányelv. 2016. URL: http://elelmiszerlanc.kormany.hu/ download/d/64/b100o/2-109_ 2016-1221.pdf (Letöltés dátuma: 2017.03.19.)

Elliott, G. R. - Cameron, R. C.: Consumer Perception of Product Quality and the Country-of-Origin Effect. Journal of International Marketing. 1992. 2 (2) 49-62.
Gerbens-Leenes, P. W. - Nonhebel, S. Krol, M. S.: Food Consumption Patterns and Economic Growth. Increasing Affluence and the Use of Natural Resources. Appetit. 2010. 55 (3) 597-608.

Ittersum, K.: The Role of Region of Origin in Consumer Decision-making and Choice. Mansholt Graduate School, Wageningen. 2002.

Lakner Z. - Gulyás M.: Élelmiszergazdasági beruházások tervezése és előkészítése. Környezet és Fejlődés Kiadó, Budapest, 2004.

Lans, I. A. - Ittersum, K. - De Cicco, A. - Loseby, M.: The Role of the Region of Origin and EU Certificates of Origin in Consumer Evaluation of Food Products. European Review of Agricultural Economics. 2001. 28 (4) 453.

Lehota J.: Az élelmiszerfogyasztói magatartás hazai és nemzetközi trendjei. Élelmiszer, Táplálkozás és Marketing. 2004. 1 (1-2) 7-14.

Magda R. - Marselek S. (szerk.): Vidékgazdaságtan I. A vidékfejlesztés gazdasági folyamatai. Szaktudás Kiadó Ház, Budapest, 2010. 15-31.

Makay P.: Az Észak-Alföldi Régió növényi eredetü hagyományos, különleges tulajdonságú termékei. 2006. URL: http://www.eoq.hu/debr/koz156-208.pdf (Letöltés dátuma: 2015.05.03.)

Malota E.: A fogyasztói etnocentrizmus. In: Hunyady Gy. - Székely M. (szerk.) Gazdaságpszichológia, Osiris Kiadó, Budapest, 2003. 297-303.

Nábrádi A.: A hagyományos és tájjellegü ételek gazdasági jelentősége. In: Berke Sz. - Biacs P. - Lehota J. - Nábrádi A. Nótári M. - Pallóné Kisérdi I. - Polereczki Zs. - Popovics A. - Szakály Z. - Szente V. - Szigeti O. - Totth G. - Zobor E. Marketing a hagyományos és tájjellegú élelmiszerek piacán, Kaposvári Egyetem Gazdaságtudományi Kar, Kaposvár, 2010.

Pallóné Kisérdi I.: A versenyképesség biztosításának új minőségidimenziója az élelmiszergazdaságban EU csatlakozásunk szempontjából, Doktori (Ph.D.) értekezés, Budapesti Közgazdaság-tudományi és Államigazgatási Egyetem, 2003. 
Rowan, C.: Innovation in Dairy Ingredients. Food Engineering \& Ingredients. 2001. (9) $41-42$.

Szabó E.: Eredet- és minőségjelzők szerepe a marketingkommunikációban. Élelmiszervizsgálati Közlemények. 2009. 55 (1) 44.

Szakály Z.: Egészségmagatartás és funkcionális élelmiszerek: Hogyan vélekednek a hazai fogyasztók? Élelmiszer, Táplálkozás és Marketing. 2009. 6 (1-2) 9.

\section{JEGYZETEK $\%$ NOTES}

Szakály Z. - Pallóné Kisérdi I. - Nábrádi A.: Marketing a hagyományos és tájjellegú élelmiszerek piacán. Kaposvári Egyetem Gazdaságtudományi Kar, Kaposvár, 2010. 13.

Szakály Z. - Polereczki Zs. - Nábrádi A. Jávor A.: A perspektivikus (funkcionális jellegü) élelmiszerek. Jubileumi Nemzetközi Táplálkozásmarketing Konferencia, Új Élelmiszerfogyasztó a Digitális Világban, Debrecen, 2014. 